\title{
Axons Regulate Schwann Cell Expression of the POU Transcription Factor SCIP
}

\author{
Steven S. Scherer, ${ }^{1}$ Da-yuan Wang, ${ }^{1}$ Rainer Kuhn, ${ }^{2, a}$ Greg Lemke, ${ }^{2}$ Lawrence Wrabetz,' and John Kamholz' \\ 'Department of Neurology, The Hospital of the University of Pennsylvania, Philadelphia, Pennsylvania 19104 and \\ 2 Molecular Neurobiology Laboratory, The Salk Institute, San Diego, California 92186
}

\begin{abstract}
SCIP (suppressed cAMP-inducible POU) is a POU domain transcription factor expressed by Schwann cells. Drugs that elevate intracellular cAMP, such as forskolin, increase the expression of SCIP and partially mimic the inductive effects of axons on Schwann cell gene expression. Thus, SCIP may be involved in a differentiation pathway in Schwann cells that is activated by axons. We have examined this issue by studying SCIP expression in developing, degenerating, and regenerating rat peripheral nerves, and in Schwann cellneuron cocultures. High levels of SCIP mRNA were detected in developing and regenerating nerves, and axotomy at these times caused the level of SCIP mRNA to plummet. Similarly, there were many SCIP-immunoreactive Schwann cell nuclei in developing and regenerating nerves, and their number fell sharply after axotomy. SCIP-immunoreactive Schwann cells were associated with axons in developing and regenerating nerves, and in Schwann cell-neuron cocultures. These data demonstrate that axons upregulate the expression of SCIP in Schwann cells, and that SCIP is expressed in Schwann cells that ensheathe axons. Thus, SCIP may mediate some of the changes in Schwann cell gene expression that accompany axonal ensheathment.
\end{abstract}

[Key words: axon-Schwann cell interactions, myelin, Wallerian degeneration, peripheral nerve, axonal regeneration, axotomy]

Myelin is a multilamellar structure that surrounds axons, thereby increasing axonal conduction velocity. It is formed by the spiral wrapping of the cell mcmbrane of myclinating glia-oligodendrocytes in the CNS and Schwann cells in the PNS. Although the myelin sheaths produced by these two cell types are structurally similar, they each contain a unique set of proteins Norton and Cammer, 1984). Proteolipid protein (PLP), myelin basic protein (MBP), and myelin-associated glycoprotein (MAG) are the major structural proteins in the CNS, while $P_{0}$, MBP, peripheral myelin protein-22 kDa (PMP-22), and MAG are the major ones in the PNS (Lemke, 1988; Spreyer et al., 1991; Snipes

\footnotetext{
Reccived May 28, 1993; reviscd Aug. 25, 1993; accepted Sept. 14, 1993.

We thank D. Pijak and D. Roling as well as Drs. M. J. Brown, M. E. Selzer, J. K. Sladky, and R. Tuttle for their help and support. Dr. V. Lee generously provided the RMO 108 antibody. This work was initiated while S.S.S. and L.W. were supported by Charles A. Dana fellowships in Neuroscience, and continued with the support of NS-0160565 (to S.S.S.).

Correspondence should be addressed to Steven S. Scherer, Department of Neurology. The Hospital of the University of Pennsylvania, 3400 Spruce Street, Philadelphia. PA 19104

Present address: Ciba-Giegy I imited, CH-4002 Basel, Switzerland.

Copyright 1994 Society for Neuroscience $0270-6474 / 94 / 141930-13 \$ 05.00 / 0$
}

et al., 1992). With the onset of myelin sheath formation, the amount of each of these myelin proteins increases sharply, both in the CNS and in the PNS (Benjamins et al., 1975; Wood and Engel. 1976; Uyemura et al., 1979), as does the rate of transcription and the steady state levels of their mRNAs (Kanfer et al., 1989; Stahl et al., 1990; Wiktorowicz and Roach, 1991). Thus, there is a coordinate program of myelin gene expression, regulated at the level of transcription, that accompanies the synthesis of myelin

Oligodendrocytes and Schwann cells differ not only in their myelin-specific proteins, but also in their dependence on axonal interactions. Cultured oligodendrocytes express relatively high levels of nnyelin-related $m$ RNAs and proteins in the absence of axons (Abney et al., 1981; McMorris, 1983; Zeller et al., 1985), whereas cultured Schwann cells express only low levels of their mRNAs and proteins (Brockes et al., 1980; Morrison et al., 1991). This difference in axonal dependence also occurs in vivo. Axotomy of the optic nerve, a CNS fiber tract, causes the levels of PLP, MBP, and MAG mRNA to fall by about $50 \%$ (Goto et al., 1990; Kidd et al., 1990; McPhilemy et al., 1990; Scherer et al., 1992), whereas axotomy of the sciatic nerve, a peripheral nerve, causes the levels of $\mathrm{P}_{17}, \mathrm{MBP}, \mathrm{PMP}-22$, and $\mathrm{MAG}$ mRNA to fall by at least 95\% (Gupta et al., 1988, 1990; Trapp et al., 1988; LeBlanc and Poduslo, 1990; Snipes et al., 1992). The axonal dependence of myelin gene expression in Schwann cells is further exemplificd by the return of high levels of $P_{11}$, MBP, PMP-22, and MAG mRNA in crushed peripheral nerves as axons regenerate (Gupta et al., 1990; LeBlanc and Poduslo, 1990; Snipes et al. 1992). Hence, even in the absence of axons, oligodendrocytes develop, differentiate, and maintain a myelinating phenotype, whereas Schwann cells require axonal interactions both to initiate and to maintain their myelinating phenotype.

How axons initiate and maintain the myelinating phenotype of Schwann cells is unknown, but drugs, such as forskolin, that increase intracellular cAMP levels can mimic, at least in part, this effect. Forskolin decreases the expression of the low-affinity nerve growth factor receptor (NGFR) and increases the expression of $\mathrm{P}_{0}$ and MBP (Lemke and Chao, 1988; Monuki et al., 1989, 1990; Morgan et al., 1991). Since these effects parallel those observed in developing and regenerating peripheral nerves as axons interact with Schwann cells (Taniuchi et al., 1986. 1988: Gupta et al.. 1988; LeBlanc and Poduslo, 1990; Scherer et al., 1993), it may be possible to study the molecular events that accompany axon-Schwann cell interactions by treating Schwann cells with forskolin. Monuki et al. $(1989,1990,1993)$ have used this approach to analyze the cxpression of the transcription factor SCIP (for suppressed cAMP-inducible POU; 
also called tst- 1 and Oct-6; He et al., 1990; Suzuki et al., 1990). SCIP is a member of the POU domain transcription factor family, and rapidly accumulates in forskolin-treated Schwann cells. The level of SCIP mRNA peaks prior to the peak in myelin gene expression both in forskolin-treated Schwann cells and in developing peripheral nerve, which led to the initial suggestion that SCIP might promote myelin gene expression (Monuki et al., 1989). In cotransfection experiments, however, SCIP inhibited the activation of $\mathrm{P}_{0}, \mathrm{MBP}$, and NGFR promoters (Monuki et al., 1990; He et al., 1991). To reconcile these data, Monuki et al. (1990, 1993) postulated that SCIP is specifically expressed in proliferating Schwann cells prior to their differentiation into postmitotic, myclinating Schwann cells, and acts to inhibit the expression of Schwann cell-specific genes as they make the transition to the myelinating phenotype (Monuki et al., 1990).

In order to test the above hypothesis, we examined SCIP expression in developing and lesioned rat sciatic nerves, in which the timing of Schwann cell proliferation and myelin gene expression are well described. SCIP mRNA expression peaked on the day of birth (Monuki et al., 1989), which is also the peak of Schwann cell proliferation, but is 2 weeks before the peak of myelin gene mRNA expression (Brown and Asbury, 1981; Stahl et al., 1990). After permanent axotomy, in which axonal regeneration is prevented, SCIP mRNA expression increased slightly but without a clear relationship to either the increase in Schwann cell proliferation or the fall in myelin gene mRNA expression. After nerve crush, in which axonal degeneration is promptly followed by axonal regeneration, SCIP mRNA expression increased to high levels in parallel to the ingrowth of regenerating axons, and preceded $\mathrm{P}_{0}$ mRNA reexpression. In addition, axotomy of developing and regenerating nerves at times when SCIP levels were relatively high caused SCIP mRNA expression to plummet. Furthermore, immunohistochemical staining demonstrated that the number of SCIP-positive Schwann cells parallels the expression of SCIP mRNA in developing, degenerating, and regenerating nerves, and that SCIP-cxpressing Schwann cells are intimately associated with axons. These data show that SCIP expression depends on axon-Schwann cell interactions in both developing and regenerating nerves. We hypothesize that SCIP is transiently expressed by Schwann cells as they ensheathe axons, and mediates some axon-dependent changes in Schwann cell gene expression.

\section{Materials and Methods}

Sciatic nerve transection and crush. Using aseptic technique, the sciatic nerves of anesthetized $(50 \mathrm{mg} / \mathrm{kg}$ pentobarbital, i.p.), adult (10-13-weekold) Sprague-Dawley rats were exposed at the sciatic notch. Some nerves were doubly ligated, and transected with iridectomy scissors, and the two nerve stumps were sutured at least $1 \mathrm{~cm}$ apart; this technique prevents axonal regeneration to the distal nerve stump for at least 2 months. Nerve crush was produced by tightly compressing the sciatic nerve at the sciatic notch with flattened forceps twice, each time for 10 sec; this technique causes all of the axons to degenerate, but allows axonal regeneration. We also transected the sciatic nerves of newborn rats, without ligating them as in adult animals, and analyzed them after $2 \mathrm{~d}$, which is insufficient time for axonal regeneration. At varying times after nerve injury, the animals were killed by $\mathrm{CO}_{2}$ inhalation, the distal nerve stumps were removed, and the most proximal $2-3 \mathrm{~mm}$ was trimmed off. For transected nerves, the entire distal nerve stump was taken from just below the lesion to the ankle (about $4 \mathrm{~cm}$ long). For crushed nerves, the distal nerve stump was divided into two equal segments, termed the proximal and distal segments, each about $2 \mathrm{~cm}$ long. The nerves were immediately frozen in liquid nitrogen and stored at $-80^{\circ} \mathrm{C}$. Unlesioned sciatic nerves were obtained from animals of varying ages, from $\mathrm{Pl}$ (the day after birth) to P90. All animal protocols were approved by the Institutional Animal Care and Use Committee of The University of Pennsylvania.

Northern blotting. RNA was isolated from rat sciatic nerves by $\mathrm{CsCl}_{2}$ gradient centrifugation (Chirgwin et al., 1979). Equal samples $(10 \mu \mathrm{g})$ of total RNA were electrophoresed in $1 \%$ agarose, $2.2 \mathrm{M}$ formaldehyde gels, transferred to nylon membranes (Duralon, Stratagene, La Jolla, CA) in $6 \times$ saline-sodium citrate (SSC) and UV cross-linked $(0.12 \mathrm{~J})$ Blots were prehybridized, hybridized, and washed using standard techniques (Sambrook et al., 1989). For rat cDNA probes, the final wash was in $0.2 \times \mathrm{SSC}$ at $65^{\circ} \mathrm{C}$ for $30 \mathrm{~min}$; for human cDNA probes, it was $2 \times$ SSC at $60^{\circ} \mathrm{C}$ for $30 \mathrm{~min}$. The following cDNAs were utilized as probes-a 0.9 kilobase $(\mathrm{kb})$ XhoI-SacII fragment of rat SCIP (Monuki et al., 1989), a full-length $\operatorname{cDN} \Lambda(2.0 \mathrm{~kb})$ of rat $\mathrm{P}_{0}$ (Lemke and Axel, 1985), a 0.7 kb BamHI fragment of rat NGFR (Radeke et al., 1987), a $0.3 \mathrm{~kb}$ PvuII fragment of human histone $\mathrm{H}-3$ (pFF435C; Plumb et al., 1983 ), and a full-length $(1.3 \mathrm{~kb}) \mathrm{cDNA}$ of rat glyceraldehyde 3-phosphate dehydrogenase (GAPDH; Fort et al., 1985). Plasmid inserts were isolated after restriction endonuclease digestion, separated by agarose gel electrophoresis, and purified by electrolution. ${ }^{32} \mathrm{P}$-labeled cDNA probes with specific activities of $2-5 \times 10^{9} \mathrm{cpm} / \mu \mathrm{g}$ were prepared by primer extension with random hexamers using the Prim-a-gene kit (Promega, Madison, WI) according to the manufacturer's instructions. Where indicated, exposed x-ray films were scanned with a Zeineh laser densitometer.

Schwann cell-neuron cocultures. Lumbar dorsal root ganglia (DRG) were obtained from $\mathrm{E} 7$ chicken embryos and cultured on laminin-coated $35 \mathrm{~mm}$ plastic dishes in Dulbecco's modified Eagle's medium/F-12, 5\% fetal calf serum, $20 \mathrm{ng} / \mathrm{ml}$ nerve growth factor, and $2 \mathrm{~mm}$ glutamine. After $2 \mathrm{~d}$ in culture, the ganglia were treated for $3 \mathrm{~d}$ with $10 \mu \mathrm{M}$ cytosine arabanoside to eliminate non-meuronal cells, and after $7 \mathrm{~d}$ in culture, rat Schwann cells (Brockes et al., 1979) were added. After a total of 10 , 15 , or $19 \mathrm{~d}$ in culture, the cultures were fixed in $4 \%$ paraformaldehyde in PBS for $15 \mathrm{~min}$, and successively incubated for $15 \mathrm{~min}$ each in the following: (1) $100 \mathrm{~mm}$ Tris ( $\mathrm{pH} 7.4$ ) containing $1 \%$ Triton $\mathrm{X}-100,1 \mathrm{~mm}$ EDTA, 1\% 2-mercaptoethanol, (2) $10 \mathrm{mM} \mathrm{BO}_{3}$ (pH 9.2) containing 10 mM dithiothreitol (DTT), and (3) $10 \mathrm{mM} \mathrm{BO}_{3}$ (pH 9.2) containing $0.3 \%$ $\mathrm{H}_{2} \mathrm{O}_{2}$. The cultures were incubated for $60 \mathrm{~min}$ in a 1:10 dilution of polyclonal rabbit antibody against rat SCIP, extensively washed, and then incubated for $60 \mathrm{~min}$ in FITC-conjugated goat anti-rabbit antibody (Kuhn et al., 1991; Collarini et al., 1992). The nuclei were counterstained with propidium iodide.

Histology. For immunohistochemistry, the distal nerve stumps of transected and crushed rat sciatic nerves, as well as unlesioned nerves, were fixed in Bouin's solution and embedded in paraffin so that transverse and longitudinal sections were obtained. After deparaffinization, endogenous peroxidase was blocked by incubation in hydrogen peroxide/methanol, and nonspecific binding was blocked by preincubation of the sections with $2 \%$ fetal calf serum. The sections were incubated overnight at $4^{\circ} \mathrm{C}$ with a $1: 10$ dilution of the primary antibody against SCIP (Kuhn et al., 1991; Collarini et al., 1992). After incubating with the primary antibody, the sections were washed extensively and then incubated with a biotinylated goat anti-rabbit IgG and avidin-peroxidase complex according to the manufacturer's instruction (Vectastain, Vector Laboratories, Inc., Burlingame, CA), and reacted with indophane as the substrate for peroxidase. Nonimmune serum was used as a control. In some experiments, the SCIP antibody and a monoclonal mouse antibody against neurofilament (RMO 108; Carden et al., 1987) were used together. The SCIP antibody was visualized as above, but the monoclonal antibody was visualized with fluorescence microscopy, after exposing the sections to fluorescein-conjugated donkey anti-mouse antibodies (Jackson ImmunoResearch Laboratories, West Grove, PA). Schwann cell nuclei were not labeled in developing, transected, or crushed nerves when normal rabbit serum was substituted for the SCIP antibody. Some sections were counterstained with $1 \mu \mathrm{g} / \mathrm{ml}$ solution of 4',6-diamidino-2-phenylindole(DAPI) to visualize nuclei. Some nerves were fixed in 3\% glutaraldehyde in $0.1 \mathrm{M}$ phosphate buffer ( $\mathrm{pH} 7.4)$. After washing in buffer, they were osmicated, dehydrated, and embedded in Epon. Sections were cut at $1 \mu \mathrm{m}$ and stained with a combination of methylene blue, azure II, and basic fuchsin (Richardson et al., 1960)

\section{Results}

SCIP expression in degenerating and regenerating nerve

In order to determine the effect of axons-Schwann cell interactions on SCIP expression, we examined the expression of SCIP 
A. TRANSECTED

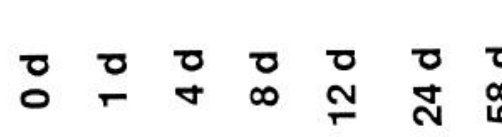

B. CRUSHED

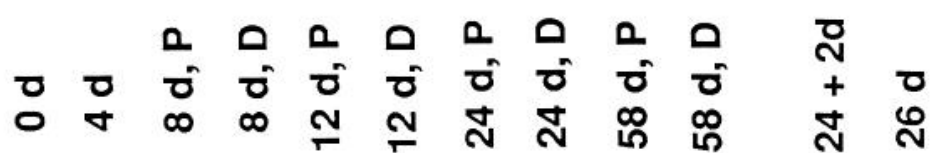

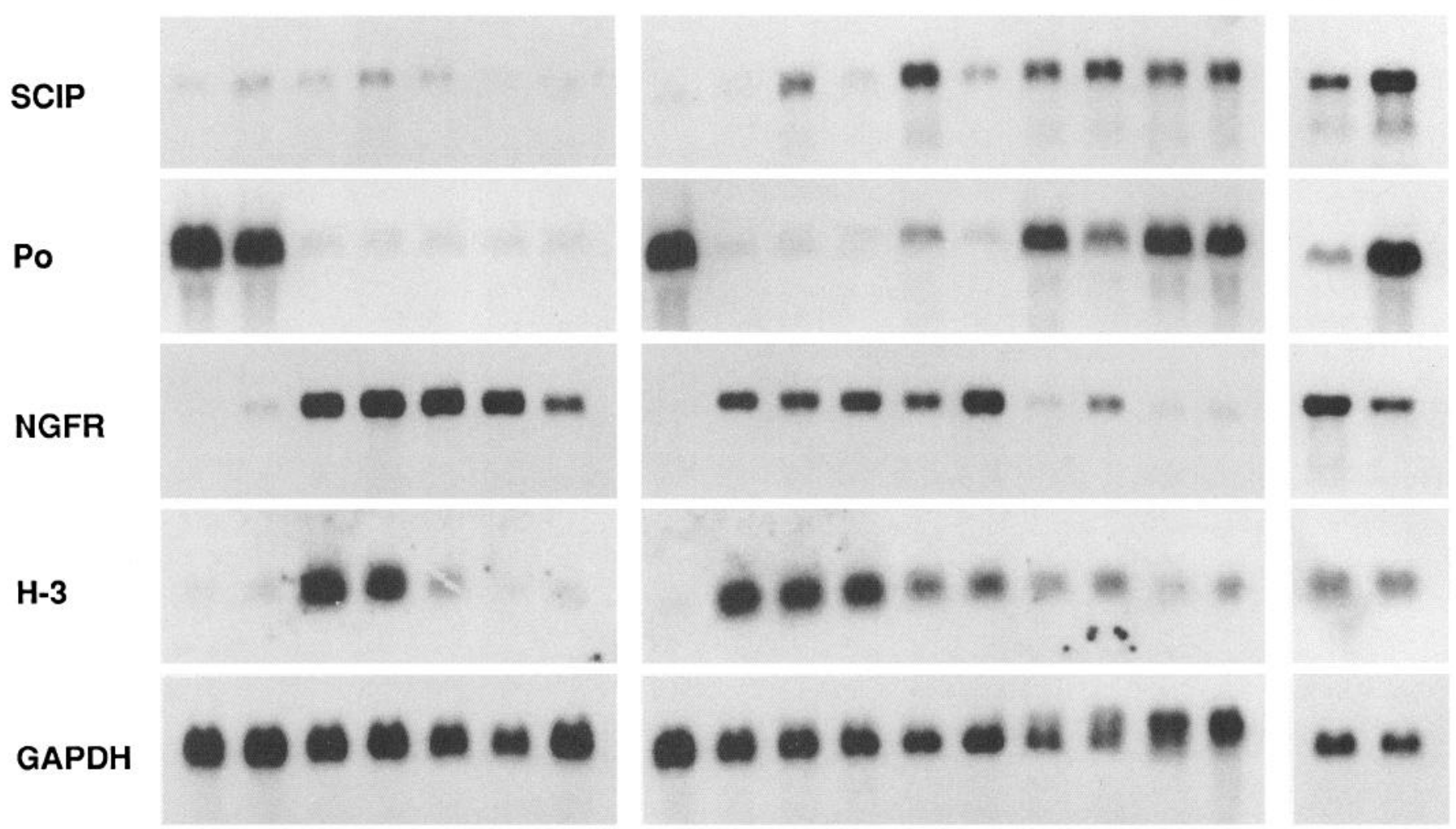

Figure 1. Northern blot analysis of normal and lesioned adult rat sciatic nerves. Each lane contains an equal amount ( $10 \mu \mathrm{g})$ of total RNA isolated from the distal stumps of sciatic nerves that had been transected $(A)$, crushed $(B)$, or transected $24 \mathrm{~d}$ after nerve crush and allowed to degenerate for an additional $2 \mathrm{~d}(C)$. The number of days after each of these lesions is indicated; the " 0 " time point is from unlesioned nerves. In crushed nerves $(B)$, the distal nerve stumps were divided into proximal $(P)$ and distal $(D)$ segments of equal lengths. The blots were successively hybridized with a radiolabeled cDNA probe for SCIP, $P_{0}$, NGFR, histone H-3 $(H-3)$, and glyceraldehyde 3-phosphate dehydrogenase (GAPDH). The films were exposed for the following times: SCIP ( $A$ and $B, 5 \mathrm{~d} ; C, 7 \mathrm{~d}), \mathrm{P}_{0}(A$ and $B, 12 \mathrm{hr} ; C, 2 \mathrm{hr}), \mathrm{NGFR}(A$ and $B, 1 \mathrm{~d} ; C, 3 \mathrm{~d}), \mathrm{H}-3(A-C, 16 \mathrm{hr})$, and GAPDH ( $A$ and $B, 16 \mathrm{hr} ; C, 6 \mathrm{hr})$.

mRNA in transected and crushed adult rat sciatic nerves. Our method of transection caused Wallerian degeneration, but prevented axonal regeneration in the distal nerve stump for at least 2 months (data not shown). Nerve crush also caused Wallerian degeneration, but allowed axonal regeneration into the distal nerve stump by $8 \mathrm{~d}$ postlesion (data not shown). Thus, by comparing the results following nerve crush to those following nerve transection, the changes in gene expression that depend on axonal regeneration can be inferred.

The steady state level of SCIP mRNA was relatively low in unlesioned adult nerves and appeared to increase slightly in the distal nerve stumps between 1 and $12 \mathrm{~d}$ posttransection (Fig. $1 A$ ). The highest level of SCIP mRNA occurred at $2 \mathrm{~d}$ posttransection (data not shown), as previously found by Monuki et al. (1990); by densitometry, this peak was threefold higher than the level in unlesioned nerves. Thus, there was a low level of SCIP mRNA in adult nerve, and it increased transiently during Wallerian degeneration.

Reprobing the same blot allowed us to compare the changes in SCIP mRNA expression to those of $\mathrm{P}_{0}$ and NGFR (Fig. 1A), which are known to change during Wallerian degeneration (Gupta et al., 1988; Mokuno et al., 1988; Trapp et al., 1988; Monuki et al., 1989; Scherer et al., 1993). The steady state level of $P_{0}$ mRNA was highest in unlesioned nerves and fell dramatically between 1 and $4 \mathrm{~d}$ posttransection, and remained at this low level for at least $58 \mathrm{~d}$. In contrast, NGFR mRNA was barely detectable in unlesioned nerves, but increased markedly between 1 and $4 \mathrm{~d}$ posttransection-exactly the opposite pattern of $\mathrm{P}_{0}$ mRNA. The steady state level of histone $\mathrm{H}-3$ mRNA, which correlates with the mitotic activity (Plumb et al., 1983), rose to a peak between 4 and $8 \mathrm{~d}$ posttransection, and then fell sharply; this parallels the profile of Schwann cell proliferation during Wallerian degeneration (Bradley and Asbury, 1970). To show that these changes were not simply due to differences in the amount of RNA per lane, we reprobed the blot for GAPDH mRNA, which yielded approximately equal signals for all of the samples. Since the profile of SCIP mRNA expression does not parallel those of $\mathrm{P}_{0}$, NGFR, or histone $\mathrm{H}-3$, it is possible that SCIP is not involved in the transcriptional changes that occur during Wallerian degeneration of adult nerve.

We also analyzed the steady state level of SCIP mRNA in the distal nerve stumps of crushed nerves. We divided the distal 


\section{A. DEVELOPMENT}

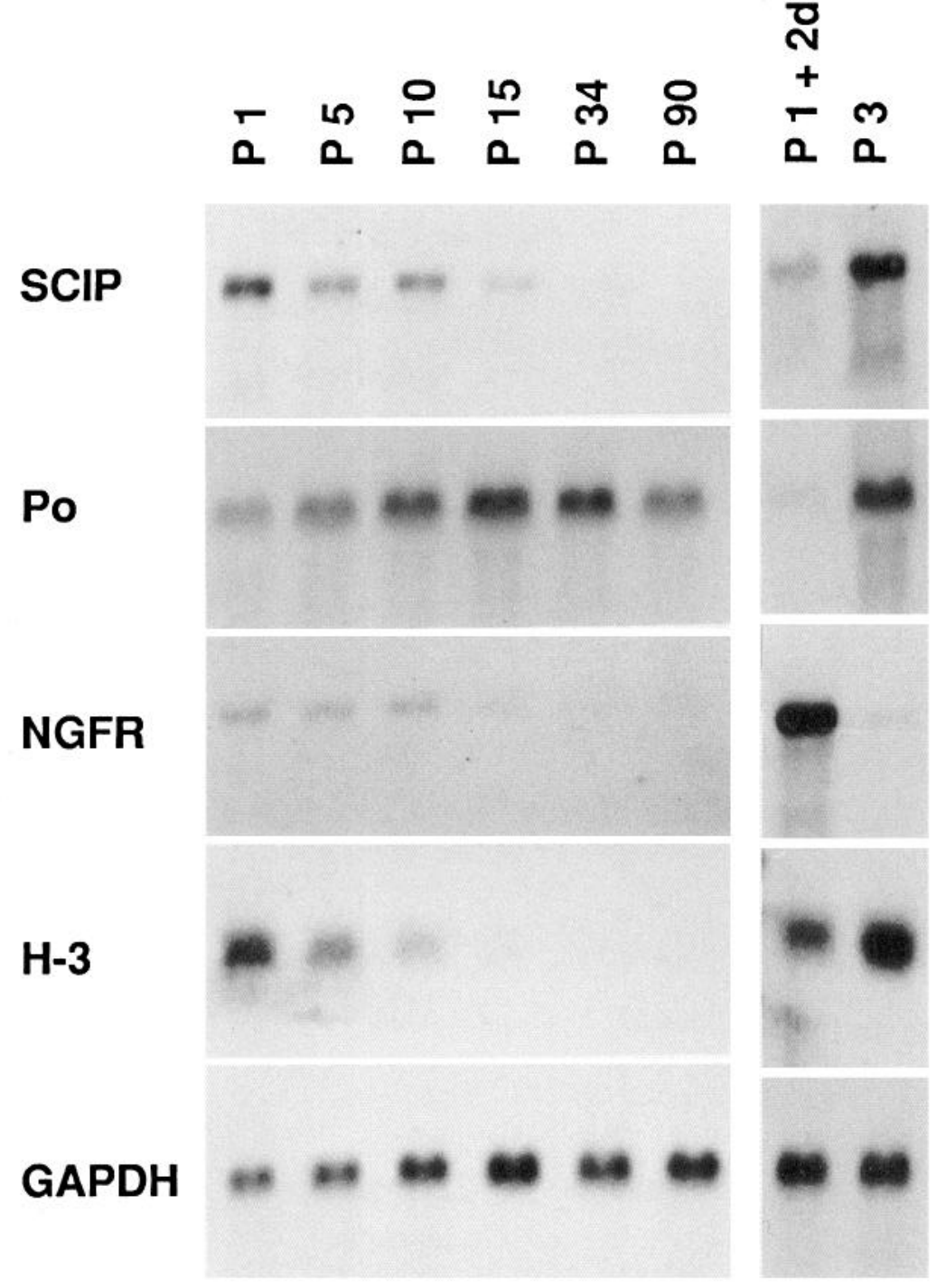

Figure 2. Northern blot analysis of rat sciatic nerves during normal development $(A)$, and after lesioning the sciatic nerve at birth $(B)$. Each lane contains an equal amount $(10 \mu \mathrm{g})$ of total RNA from normal animals ranging in age between $\mathrm{P} 1$ and $\mathrm{P} 90$ ( $P$, days postnatal) $(A)$, and from $\mathrm{P} 3$ animals $(B), 2 \mathrm{~d}$ after transecting the left sciatic nerve; the unlesioned right nerves were used for comparison. The blots were successively hybridized with a radiolabeled cDNA probe for SCIP, $\mathrm{P}_{0}$, NGFR, $\mathrm{H}-3$, and GAPDH. The films were exposed for the following times: SCIP $(A, 5 \mathrm{~d}$; $B, 3 \mathrm{~d}), \mathrm{P}_{0}(A$ and $B, 12 \mathrm{hr}), \operatorname{NGFR}(A$, $10 \mathrm{~d} ; B, 3 \mathrm{~d}), \mathrm{H}-3(A, 3 \mathrm{~d} ; B, 1 \mathrm{~d})$, GAPDH ( $A$ and $B, 1 \mathrm{~d}$ ). nerve stumps of crushed nerves into a proximal and a distal segment, as axons regenerate in a proximal-to-distal direction. This analysis allowed a better appreciation of the axonal dependence of Schwann cell gene expression (Mitchell et al., 1990), as shown in Figure $1 B$. The level of SCIP mRNA was unchanged at $4 \mathrm{~d}$ postcrush, but increased dramatically in the proximal segment beginning at $8 \mathrm{~d}$, and in the distal segment beginning at $12 \mathrm{~d}$; these times correspond with the arrival of large numbers of regenerating axons into these portions of the distal nerve stump (data not shown). The level of SCIP mRNA peaked at $12 \mathrm{~d}$ in the proximal segment, and at $24 \mathrm{~d}$ in the distal segment, and was still elevated in both segments at $58 \mathrm{~d}$. By densitometry, the peak level of SCIP mRNA in the proximal segment at 12 d was 10 -fold higher than that in unlesioned nerves. Hence, both the high level of SCIP mRNA in crushed nerves and the time course of its expression indicate that regenerating axons led to the increased expression of SCIP.

In order to compare the expression of SCIP mRNA in the distal nerve stumps of crushed nerves to the those of $\mathrm{P}_{0}, \mathrm{NGFR}$, and histone $\mathrm{H}-3$, the blot was reprobed (Fig. $1 B$ ). The steady state level of $P_{0}$ mRNA initially fell abruptly, but returned by
$12 \mathrm{~d}$ postlesion in the proximal segment, and by $24 \mathrm{~d}$ in the distal segment; by $58 \mathrm{~d}$ the levels in both segments were roughly equal. In contrast, NGFR mRNA was barely detectable in unlesioned nerves, increased markedly between 1 and $4 \mathrm{~d}$ postcrush, and fell markedly after $12 \mathrm{~d}$ postcrush. The steady state level of histone H-3 mRNA increased abruptly after crush, peaking between 4 and $8 \mathrm{~d}$, and then fell gradually between 12 and 58 $\mathrm{d}$ postlesion. These data differ from those in transected nerves in several respects, all of which are inferred to be related to the influence of regenerating axons on Schwann cells: the reexpression of $\mathrm{P}_{0}$ mRNA, the earlier and more complete fall in NGFR mRNA, and the sustained level of histone H-3 mRNA between 12 and $58 \mathrm{~d}$ postlesion are consistent with previous reports that axons upregulate myelin gene expression, downregulate NGFR expression, and cause Schwann cell proliferation, respectively (Pelligrino and Spencer, 1985; Taniuchi et al., 1986, 1988; Mokuno et al., 1988; Gupta et al., 1990; LeBlanc and Poduslo, 1990; Monuki et al., 1990; Snipes et al., 1992; Scherer et al., 1993).

To substantiate further the role of regenerating axons in the upregulation of SCIP mRNA expression, we transected the left 
sciatic nerve $24 \mathrm{~d}$ after crush, when SCIP mRNA levels were relatively high. These animals were killed after 2 additional d, and RNA was prepared from the distal stumps of these relesioned nerves and from the contralateral ones, which had been crushed $26 \mathrm{~d}$ earlier. Figure $1 C$ is a Northern blot prepared from these samples, and shows that the steady state level of SCIP mRNA fell $2 \mathrm{~d}$ posttransection. The blot was reprobed, revealing that the levels of $P_{0}$ and NGFR mRNA fell and rose, respectively, just as in nerves that were lesioned once. In contrast, histone H-3 mRNA levels did not change, presumably because $2 \mathrm{~d}$ was too brief for degeneration-dependent proliferation to occur. These data, taken together, demonstrate that axons upregulate SCIP mRNA expression in regenerating peripheral nerves, and that this upregulation requires sustained axon-Schwann cell interactions. Furthermore, the profile of SCIP mRNA expression more closely parallels that of myelin gene expression than proliferation in regenerating nerves.

\section{SCIP expression in developing nerve}

Since axon-Schwann cell interactions were necessary for the high levels of SCIP expression in regenerating adult peripheral nerves, we also examined the level of SCIP mRNA during development. As previously reported (Monuki et al., 1989), it was highest at $\mathrm{P} 1$ and declined rapidly thereafter (Fig. 2A). Reprobing the blot demonstrated that NGFR and histone $\mathrm{H}-3$ mRNA expression had similar developmental profiles, whereas $\mathbf{P}_{0}$ mRNA expression increased from $\mathrm{Pl}$ to a peak at P33 (Monuki et al., 1989: Stahl et al., 1990). These data show that in developing nerves, in contrast to regenerating nerves, the profile of SCIP mRNA expression correlated with Schwann cell proliferation, and not with myelin gene expression.

To show whether axons were necessary for the high level of SCIP mRNA in developing nerves, the left sciatic nerve was transected on $P 1$ and the animals were killed $2 \mathrm{~d}$ later. RNA was isolated from both the transected and the unlesioned contralateral nerves, and analyzed by Northern blotting (Fig. $2 B$ ). The steady state levels of SCIP, $\mathrm{P}_{0}$, and histone $\mathrm{H}-3 \mathrm{mRNA}$ all fell markedly in the distal nerve stumps $2 \mathrm{~d}$ posttransection, whereas the steady state level of NGFR mRNA increased. Hence, in developing nerves, axotomy markedly decreased the expression of myelin genes and increased the expression of NGFR mRNA, just as in adult nerves (Brockes et al., 1980; Mirsky et al., 1980; Winter et al., 1982). In addition, axotomy decreased Schwann cell proliferation (Komiyama and Suzuki, 1992). This decreased proliferation is probably caused by the degeneration of axons, which contain mitogens for Schwann cells (Wood and Bunge, 1975). Thus, sustained axon-Schwann cell interactions are necessary for the normal pattern of Schwann cells gene expression during peripheral nerve development.

\section{Immunohistochemistry of SCIP in peripheral nerve}

To identify SCIP-expressing cells in developing sciatic nerves, we used a previously charactcrized polyclonal antibody against
SCIP (Kuhn et al., 1991; Collarini et al., 1992). Only Schwann cell nuclei were labeled, which have a characteristic elliptical shape that distinguishes them from the nuclei of endoneurial fibroblasts, mast cells, and capillary endothelial cells (Asbury and Johnson, 1978). There were many SCIP-positive nuclei at Pl, P3, P5, and PlO (Figs. 3, 4), but it was not possible to determine accurately whether the absolute or even the relative numbers of SCIP-positive nuclei changed between $\mathrm{P} 1$ and $\mathrm{P} 10$ because the number of positive nuclei varied significantly between different nerve fascicles, and the difficulty in counting unlabeled nuclei. We could only roughly estimate the relative number of SCIP-positive nuclei by comparing the number of SCIP-positive to DAPI-positive nuclei in the same microscopic field. At most, $10 \%$ of the Schwann cell nuclei were SCIP positive between $\mathrm{PI}$ and $\mathrm{PIO}$, and many areas contained fewer labeled nuclei. The number of SCIP-positive nuclei was clearly lower by P20, and none were seen in P90/adult nerves (Figs. 3, 4). Since SCIP expression paralleled proliferation in developing nerves, it was of interest that none of the mitotic figures was immunoreactive for SCIP. Thus, it is possible that SCIP is not expressed in proliferating Schwann cells in developing nerves, although we cannot exclude other explanations for this observation. These data show that only Schwann cells express SCIP immunoreactivity, the extent of which roughly parallels SCIP mRNA expression in developing nerves. Furthermore, the lack of SCIP-positive Schwann cclls, along with the low level of SCIP mRNA in adult nerves, indicates that mature myelinating and nonmyelinating Schwann cells express relatively little SCIP.

To learn whether axons were necessary for the expression of SCIP protein during development, we analyzed $\mathrm{P} 3$ nerves that had been axotomized at Pl. Examining $1-\mu \mathrm{m}$-thick epoxy sections revealed that extent of myelination (both the number of myelinated axons and the myelin sheath thickness) varied considerably between different fascicles at Pl (Webster and Favilla, 1984), and that transection at Pl caused all of the myelinated axons to degenerate by P3 (data not shown). We also examined unlesioned P3 nerves and P3 nerves that had been transected at $\mathrm{P} 1$ by labeling them with antibodies against neurofilament and SCIP. In unlesioned nerves, there were many SCIP-positive nuclei, the number of which varied between different fascicles. The neurofilament-positive axons intermingled extensively with the SCIP-positive nuclei, so that it was not possible to relate individual labeled nuclei to individual axons (Fig. 4A,B). In lesioned nerves, there was a dramatic loss of both axons and SCIP-positive nuclei (Fig. 4C,D). These data demonstrate axotomy of developing nerves causes the number of SCIP-immunoreactive nuclei to fall in parallel with the fall in SCIP mRNA (see above), further substantiating the idea that SCIP expression during development depends on axon-Schwann cell interactions,

To correlate the expression of SCIP MRNA and with SCIP immunoreactivity after nerve lesions, we examined sections of the distal nerve stumps of transected and crushed adult ncrves

Figure 3. Immunohistochemical localization of SCIP in developing rat sciatic nerves. Longitudinal sections of $\mathrm{P} 10(A, B), \mathrm{P} 20(C, D)$, and $\mathrm{P} 90$ $(E, F)$ nerves, labeled with the SCIP antibody $(A, C, E)$ and DAPI $(B, D, F)$. The SCIP-positive Schwann cell nuclei are the dark, elliptical objects in $A$ and $C$. The most immunoreactive nuclei are indicated by the arrowheads in $B$ and $D$, but other faintly stained nuclei may be seen in $A$ and $C$. Note that the DAPI staining is largely "quenched" by the superimposed peroxidase staining in the labeled nuclei. The number of SCIP-positive nuclei in $C$ is misleading, as most fields had fewer positive nuclei. No SCIP-positive nuclei are seen at P90 $(E, F)$, although there are Schwann cell nuclei present (arrowheads). $E$ shows a mast cell, which has cytoplasmic staining but an unstained nucleus $(n)$, and a capillary endothelial cell $(c)$. The labeling in the mast cell cytoplasm is caused by endogenous peroxidase activity, as mast cells were also labeled when the primary antibody was omitted. Scale bar, $10 \mu \mathrm{m}$. 

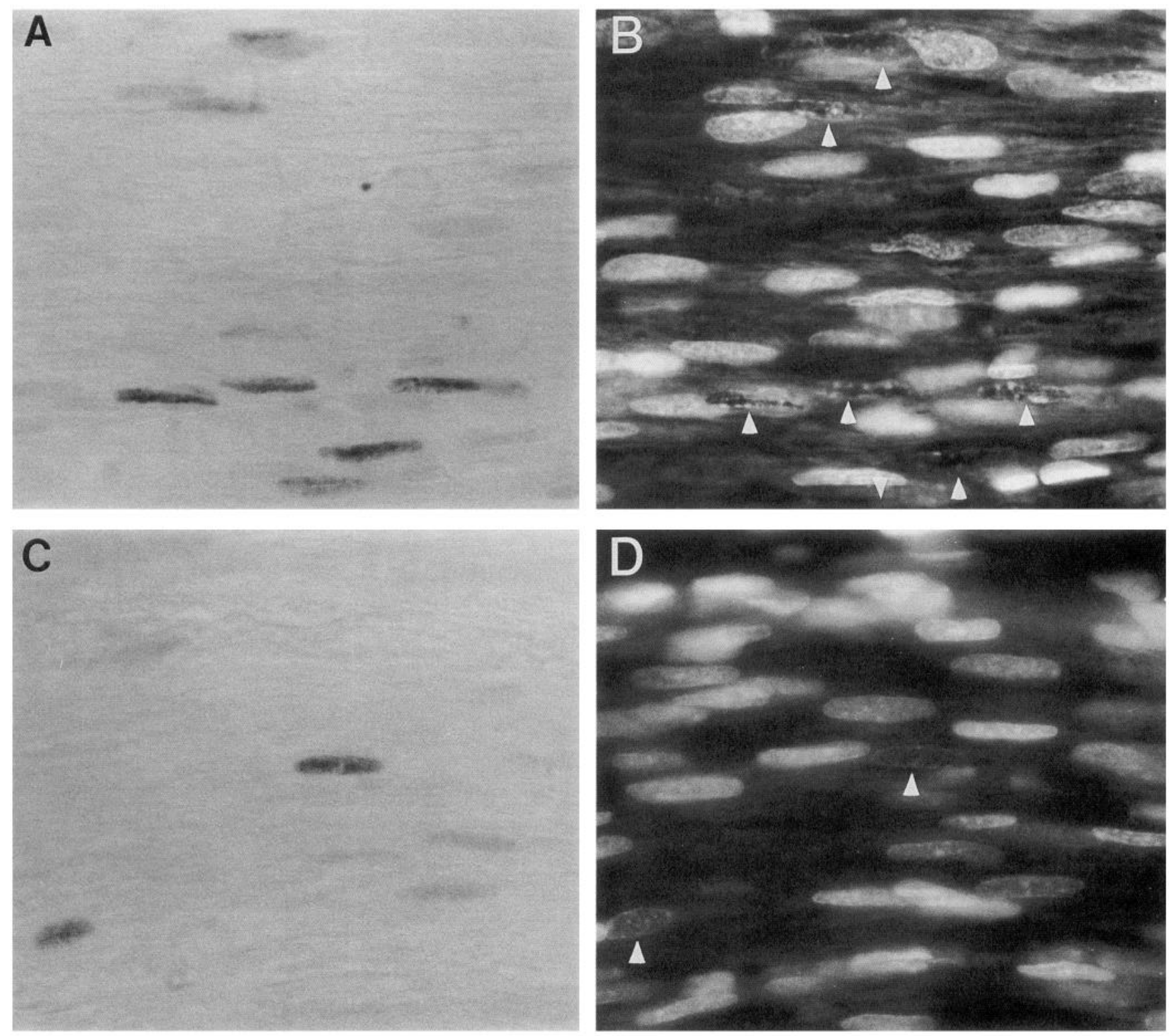

E

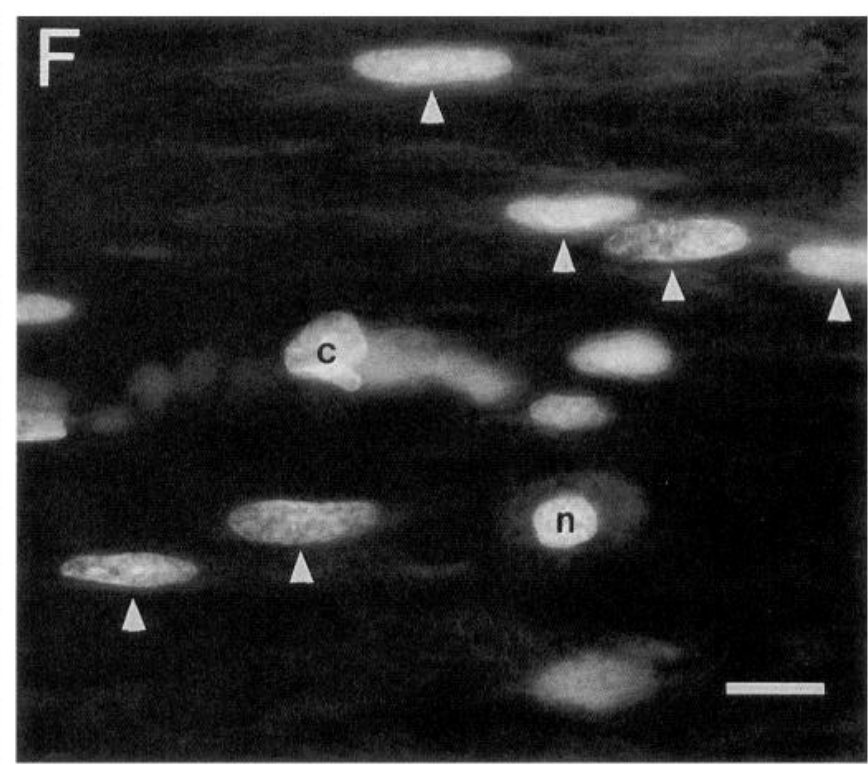



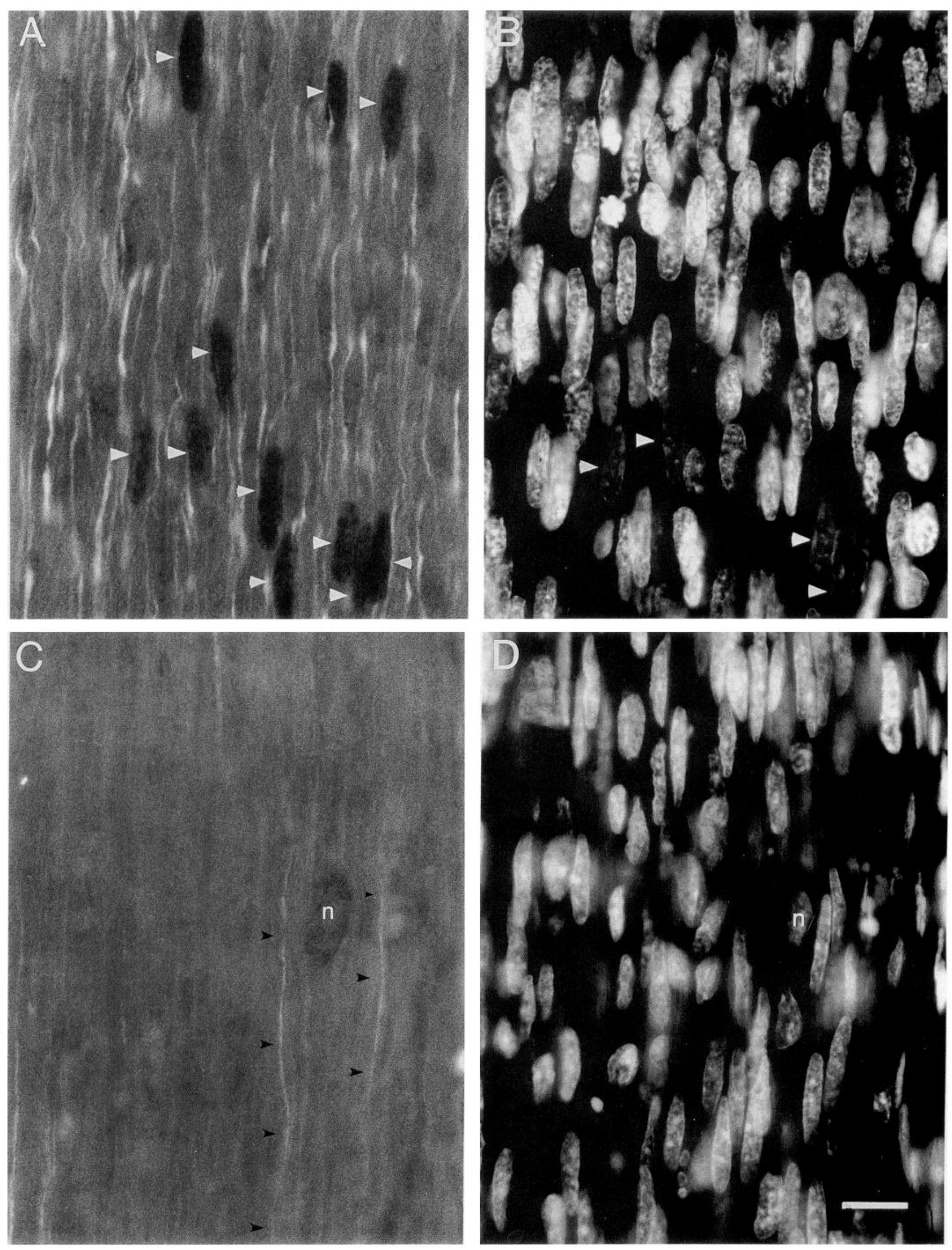
labeled with the combination of neurofilament and SCIP antibodies. There were no SCIP-immunoreactive Schwann cell nuclei at $2,12,24$, and $58 \mathrm{~d}$ posttransection (Fig. $5 \mathrm{~A}$ ), which is in keeping with the Northern blot data. In crushed nerves, in contrast, there were many SCIP-positive Schwann cells at 12, 24, and $58 \mathrm{~d}$ postlesion. SCIP-positive nuclei were far more numerous than mitotic figures at these times, and no SCIP-positive mitotic figures were seen. The double labeling of sections for neurofilaments and SCIP allowed us to determine that SCIPpositive Schwann cells were almost always clearly associated with regenerating axons, examples of which are shown in Figure $5, B$ and $C$. Moreover, at $12 \mathrm{~d}$ postcrush, there was a proximalto-distal gradient of regenerating axons and SCIP-positive Schwann cells. The most intensely stained Schwann cell nuclei were typically associated with relatively large axons in the proximal segment (Fig. $5 B$ ), whereas the thinner axons in the distal segment were associated with lightly stained nuclei. At 24 and $58 \mathrm{~d}$ postcrush, we did not appreciate a gradient in the number of either regenerating axons or SCIP-positive Schwann cells in the distal nerve stump. These data demonstrate that the upregulation SCIP immunoreactivity in regenerating nerves happens when regenerating axons interact with Schwann cells. While it seems more likely that direct physical interaction between regenerating axons and Schwann cells is necessary for the upregulation of SCIP, these data do not exclude the possibility the signal for SCIP upregulation is diffusible and acts over short distances (Bolin and Shooter, 1993).

\section{Immunocytochemistry of SCIP in Schwann cell-neuron cocultures}

While the above data clearly demonstrate that SCIP-positive Schwann cells ensheath axons, we were unable to determine exactly which Schwann cells were labeled. Webster and Favilla (1984) have described several possible relationships between Schwann cells and the axons they invest leading to the formation of mature myelinating and nonmyelinating Schwann cells. Hence, it is possible that SCIP is uniquely expressed by a subpopulation of ensheathing Schwann cells. To better characterize SCIP-expressing Schwann cells, we examined cocultures of rat Schwann cells and chicken DRG under conditions that did not permit myelination. After $2 \mathrm{~d}$ of coculture, there were proliferating Schwann cells in contact with neurites (Wood and Bunge, 1975), but no SCIP-immunorcactive nuclci were scen (data not shown). After $8 \mathrm{~d}$ of coculture, there were scattered regions that contained SCIP-positive Schwann cell nuclei; these were always in regions that contained neurites (seen by phase-contrast microscopy), but even in neurite-rich regions, only a small proportion of the Schwann cell nuclei were labeled. Some of the labeled Schwann cell nuclei formed a striking, linear pattern that precisely paralleled the orientation of neurites in that region (Fig. 6). By $12 \mathrm{~d}$ of coculture, the number of SCIP-positive Schwann cell nuclei had decreased substantially. At no time were my- elinated fibers seen in these cocultures, and Schwann cells cultured for a similar length of time in the absence of neurities were not SCIP positive. Thus, in this coculture system SCIP is transiently expressed by nonproliferating Schwann cells as a result of axon-Schwann cell interactions.

\section{Discussion}

We have investigated the expression of SCIP in the sciatic nerve during development, Wallerian degeneration, and axonal regeneration. Figure 7 is a schematic comparison of the pattern of SCIP mRNA expression to those of $\mathrm{P}_{0}$, NGFR, and histone H-3. In agreement with the findings of Monuki et al. (1989), the level of SCIP mRNA is highest at birth and falls as the level of $\mathrm{P}_{0} \mathrm{mRNA}$ is increasing. The increase in SCIP $\mathrm{mRNA}$ expression in transected nerves (Monuki et al., 1990), however, was much smaller than that in crushed nerves. These data suggest that high levels of SCIP mRNA and protein depend on axon-Schwann cell interactions, which we have directly demonstrated in two additional ways. First, axotomy at birth or during axonal regeneration of adult nerves results in a prompt fall in the level of SCIP mRNA and number of SCIP-positive Schwann cell nuclei. Second, in developing and regenerating nerves, as well as in Schwann cell-neuron cocultures, SCIPpositive Schwann cells were only seen in association with axons/ neurites. Hence, SCIP expression depends on axon-Schwann cell interactions, and its transient expression in developing nerves indicates that it may mediate some of the changes in Schwann cell gene expression that are associated with axonal ensheathment.

\section{SCIP and axon-Schwann cell interactions}

The transient expression of SCIP in developing nerves has important implications regarding its role as a transcription factor in Schwann cells. If the effect of SCIP as a transcription factor can be directly related to its mRNA level, then we may infer SCIP is unlikely to mediate the different patterns of gene expression that characterize myelinating and nonmyelinating Schwann cells, which are the two kinds of Schwann cells in unlesioned adult peripheral nerve (Mirsky and Jessen, 1990). Nonmyelinating Schwann cells ensheath but do not myelinate axons, and express glial fibrillary acid protein (GFAP), NGFR, neural cell adhesion molecule (N-CAM), and the cell adhesion molecule L1, but not $\mathrm{P}_{0}$, MBP, PMP-22, and MAG (Mirsky and Jessen, 1990; Snipes et al., 1992). Conversely, myelinating Schwann cells express $\mathrm{P}_{0}$, MBP, PMP-22, and MAG, but none of the markers of nonmyelinating Schwann cells (Mirsky and Jessen, 1990). Since the level of SCIP mRNA is low and SCIPimmunoreactive Schwann cell nuclei are absent in adult nerve, SCIP is unlikely play a role in maintaining either the myelinating or the nonmyelinating phenotype. Similarly, after permanent axotomy, SCIP mRNA expression increases only modestly, and SCIP-immunoreactive Schwann cell nuclei are absent, making

\footnotetext{
Figure 4. Immunohistochemical localization of SCIP in lesioned and unlesioned P3 rat sciatic nerves. In $A$ and $C$, SCIP and neurofilament immunoreactivity are shown together by performing a double exposure with epifluorescent and transmitted light. In $B$ and $D$, the nuclei have been stained with DAPI. A, Longitudinal section of a P3 nerve. The SCIP-positive nuclei are the dark, elliptical objects; the most heavily labeled ones are indicated by arrowheads. The axons are the fine, linear structures that are oriented parallel to the long axis of the Schwann cell nuclei. $B$, DAPI staining of the same field shown in $A$. The positions of some of the most heavily labeled Schwann cell nuclei are indicated by arrowheads to show the quenching of the DAPI stain by the chromagen. $C$, Longitudinal section of a P3 nerve, $2 \mathrm{~d}$ posttransection. There are no SCIP-immunoreactive nuclei in this field. A few neurofilament-positive axons are present (arrowheads). The dark cell is a mast cell, which has cytoplasmic staining owing to endogenous peroxidase activity, but an unstained nucleus $(n)$. D. DAPI staining of the same field shown in $C$. Scale bar, $10 \mu \mathrm{m}$.
} 

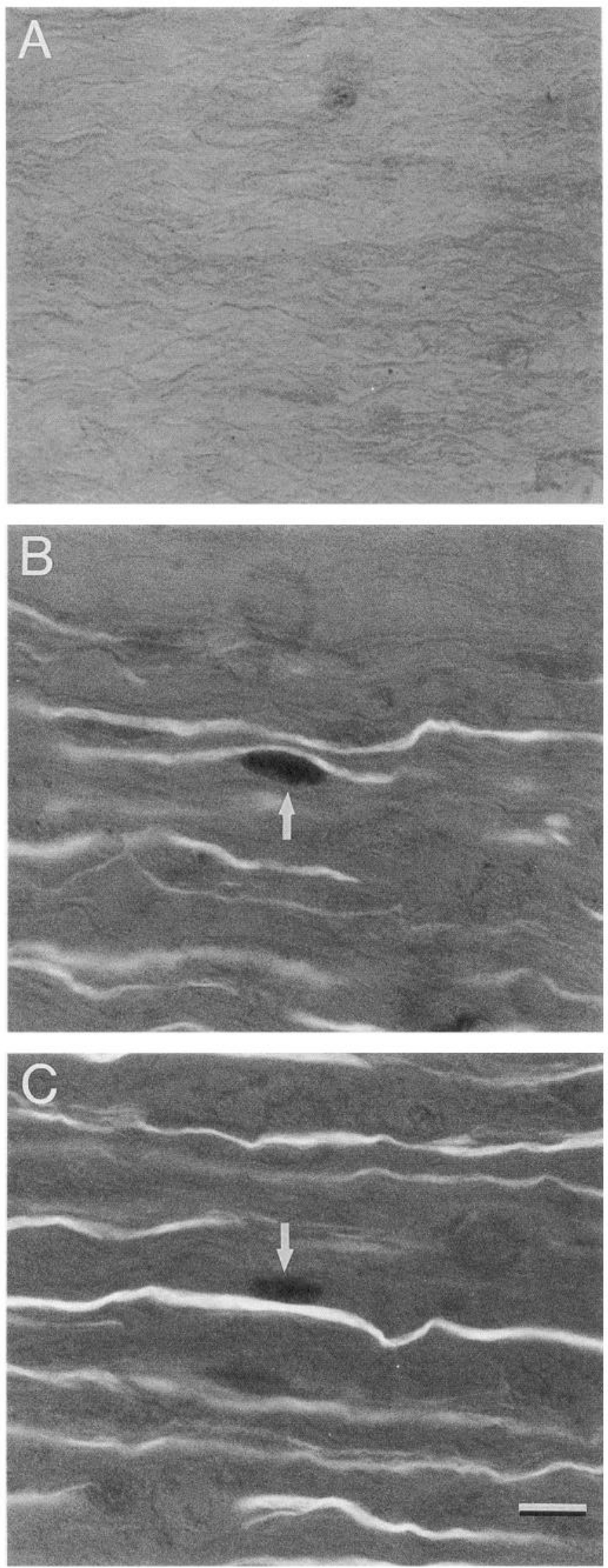

Figure 5. Immunohistochemical localization of SCIP in transected and crushed adult rat sciatic nerves. SCIP and neurofilament immunoreactivity are shown together by performing a double exposure with epiflu- it unlikely that SCIP plays a role in mediating the profound changes in Schwann cell gene expression that follow the loss of axonal interactions (reviewed by Mirsky and Jessen, 1990; Scherer and Asbury, 1993).

Rather, the pattern SCIP expression in developing and regenerating nerves indicates that it is one of the first genes to be upregulated by axon-Schwann cell interactions and, hence, is well suited to regulate the expression of other axonally dependent genes. SCIP mRNA expression in developing and regenerating nerves precedes the upregulation of myelin-related mRNAs, as in forskolin-treated Schwann cells (Monuki et al., 1989). What role SCIP plays in Schwann cells as they interact with axons is not known, and it will be crucial in this regard to learn exactly which Schwann cells express SCIP. Electron microscopy of developing nerves reveals a variety of possible axonSchwann cell interactions during enstheathment-mitotic Schwann cells in contact with axons, Schwann cells ensheathing bundles of axons, and Schwann cells in various stages of forming a myelin sheath around an axon (Webster and Favilla, 1984). All of these axon-Schwann cell relationships are also seen in regenerating nerves (Morris et al., 1972; Scherer and Easter, 1984). Thus, it is likely that the same kind(s) of Schwann cells express SCIP in developing and regenerating nerves, so that SCIP may serve a similar role in both situations. Some possible roles of SCIP in Schwann cells are considered below.

\section{SCIP and Schwann cell proliferation}

Do proliferating Schwann cells express SCIP? In developing sciatic nerve, SCIP levels and Schwann cell proliferation fall in parallel (Brown and Asbury, 1981; Monuki et al., 1990). Furthermore, SCIP is expressed at high levels in Schwann cells cultured with forskolin, which is a mitogen for Schwann cells (Monuki et al., 1989). Finally, there is a small peak of SCIP mRNA expression prior to the onset of proliferation in transected nerves (Monuki et al., 1990). While these findings support the idea that proliferating Schwann cells express SCIP, several others contradict it. First, we did not find any mitotic figures that were SCIP positive. Second, at the peak of Schwann cell proliferation in Wallerian degeneration, SCIP mRNA levels have already declined (Fig. 7). Third, in crushed/regenerating nerves, there was no relationship between SCIP mRNA levels and proliferation (Fig. 7), and SCIP-positive cells were much more numerous than mitotic Schwann cells.

One hypothesis that would be consistent with these data is that SCIP is related to Schwann cell proliferation only in developing nerves. We have shown that axotomy of P1 nerves leads to a reduction of Schwann cell proliferation, which is probably due to the loss of an axonal mitogen(s) (Wood and Bunge, 1975; Salzer et al., 1980a,b; Ratner et al., 1988). Perhaps the axonal mitogen that causes Schwann cell proliferation in developing nerves leads to increased SCIP expression, whereas the mitogen(s) that causes proliferation in degenerating nerves, which may originate from myelin sheaths (Salzer and Bunge, 1980; Baichwal et al., 1988), does not. One would also have to postulate that the mitogenic response of Schwann cells to re-

orescent and transmitted light. $A$, Longitudinal section of a nerve $12 \mathrm{~d}$ posttransection. There are no axons or SCIP-positive nuclei in this field. $B$ and $C$, Longitudinal section of a nerve $12 \mathrm{~d}$ postcrush. SCIP-positive nuclei are indicated by arrows, and the axons are the fine, horizontally running, linear structures. Scale bar, $10 \mu \mathrm{m}$. 

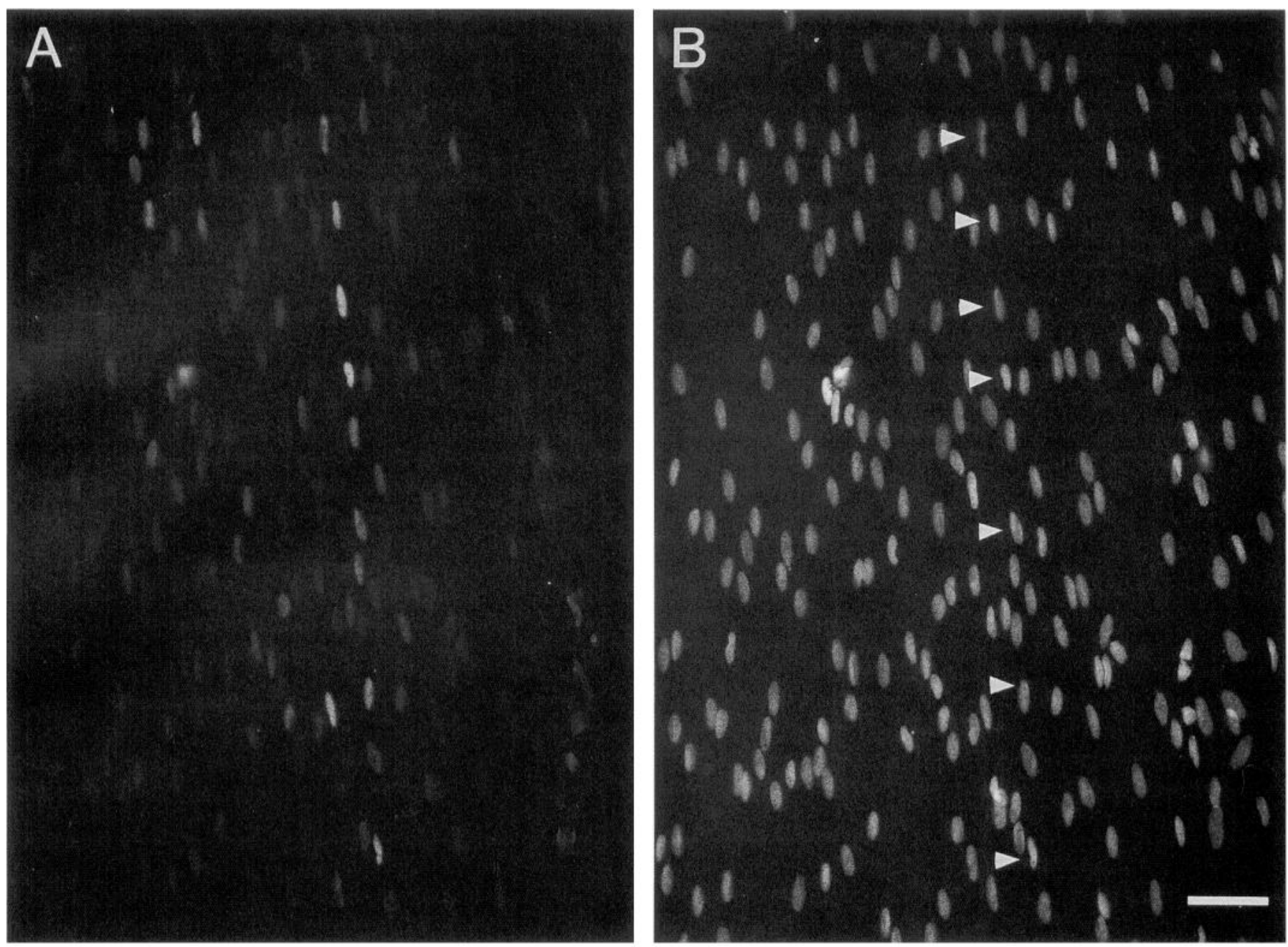

Figure 6. Immunocytochemistry of rat Schwann cells cocultured with chicken sensory neurons. $A$, SCIP-positive Schwann cell nuclei are seen in a region that contains many neurites, and a row of strongly positive nuclei runs down the center of the figure. $B$, Propidium iodide demonstrates all of the nuclei in the same field as $A$; some of the labeled nuclei are indicated by arrowheads. Scale bar, $50 \mu \mathrm{m}$.

generating axons (Pelligrino and Spencer, 1985) is caused by yet another mitogen that does not increase SCIP expression, as proliferation and SCIP expression are not correlated in regenerating nerves. Although we consider it unlikely, it remains a formal possibility that SCIP expression is linked to Schwann cell proliferation in some instances and not in others.

\section{SCIP and ensheathing Schwann cells}

In developing and regenerating nerves, there are at least two kinds of ensheathing Schwann cells. Some ensheathe bundles of axons ("premyelinating" Schwann cells), whereas others, socalled "promyelinating" Schwann cells, ensheathe single axons before forming a myelin sheath (Morris et al., 1972; Scherer and Easter, 1984; Webster and Favilla, 1984). We suspect that SCIP is expressed by promyelinating Schwann cells, as in regenerating nerves, there were many, strongly SCIP-positive Schwann cells that appeared to be associated with relatively large, single axons. This observation needs to be confirmed by electron microscopy, as the the resolution of light microscopy is insufficient to allow us to distinguish single axons from bundles of axons confidently (Scherer and Easter, 1984). In addition, SCIP is expressed in tellurium neuropathy, which a purely demyelinating neuropathy in which Schwann cells remain in a 1:1 association with demyelinated axons (Toews et al., 1991). The prolonged period of SCIP expression in the distal nerve stump of crushed nerves is not inconsistent with the idea that SCIP is expressed in promyelinating Schwann cells, as the remyelination of regenerated axons is similarly prolonged (Gutmann and Sanders, 1943; Mira, 1976). Thus, while these data indirectly support the conclusion that SCIP is expressed by promyelinating Schwann cells, further work is required.

We have shown that axotomy causes SCIP expression to fall in developing nerves. It is also important to consider what causes SCIP expression to fall in normal development, in which Schwann cells remain associated with the axons they ensheath and/or myelinate. It is not an irreversible change in Schwann cells, as regenerating axons in adult nerves can reinduce SCIP expression. In addition, forskolin maintains indefinitely the expression of SCIP in cultured Schwann cells (Monuki et al., 1989), indicating that Schwann cells may be able to maintain its expression. The transient expression of SCIP in normal development could be caused by a transient, axonal stimulus. Alternatively, the axonal signal could be maintained, and the expression of SCIP actively suppressed, in the Schwann cells of adult nerves. While we do not have any data that bear directly on this issue, the possibility that SCIP expression is actively 

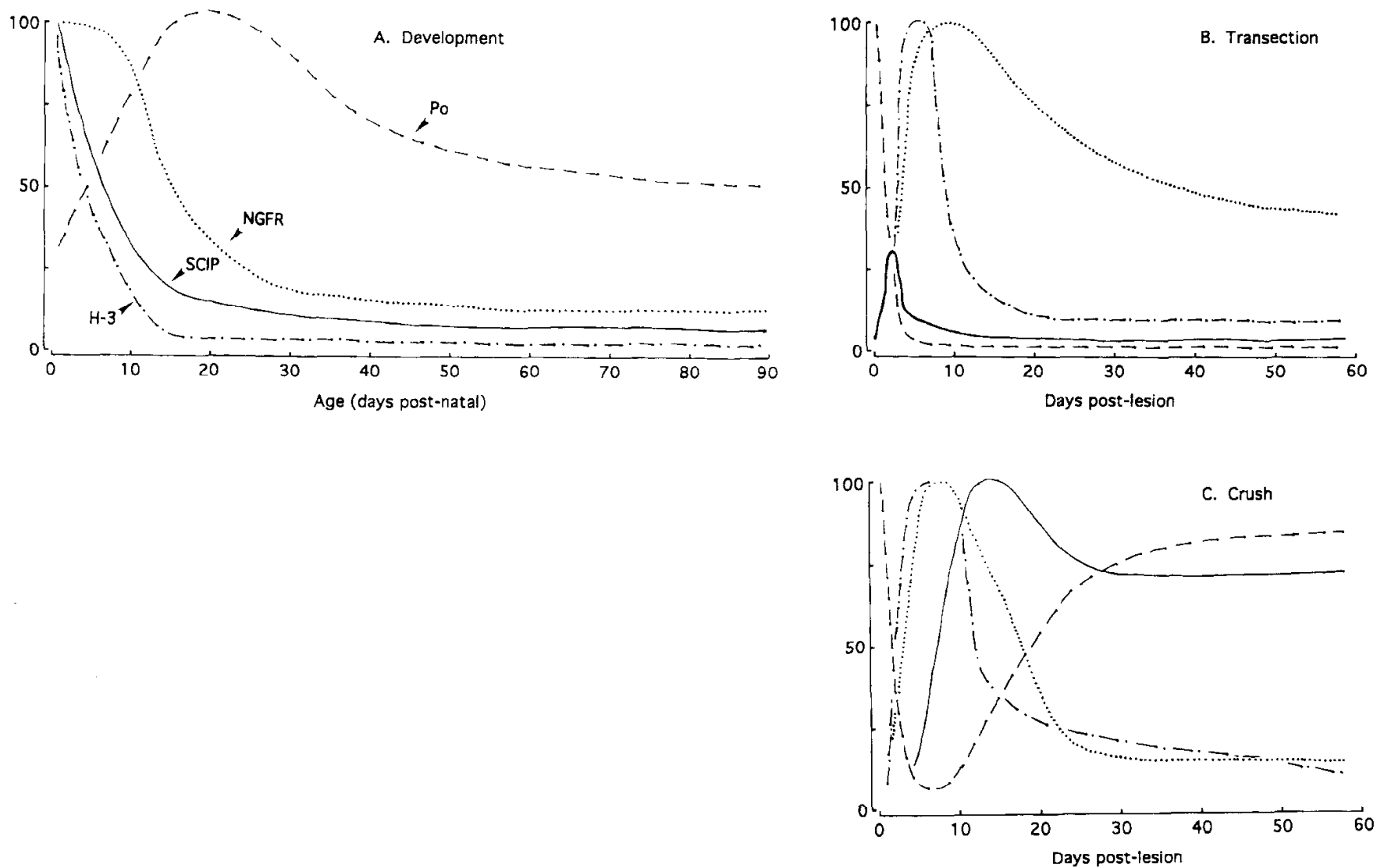

Figure 7. Schematic summary of SCIP, $\mathrm{P}_{0}$, NGFR, and histone H-3 mRNA expression in developing $(A)$, transected/degenerating $(B)$, and crushed/ regenerating rat sciatic nerves $(C)$. The films shown in Figures 1 and 2 were analyzed by densitometry, and the highest signal on each film was assigned a value of 100 . In crushed nerves, we used the value of the proximal portion of the distal nerve stump at $8,12,24$, and $58 \mathrm{~d}$ postlesion. In this way, the relative levels of $P_{0}$, NGFR, and histone H-3 mRNA were determined for each blot. To normalize the relative changes in SCIP mRNA in transected and crushed nerves, however, we compared signals on a blot (not shown) that contained samples from transected nerves and from the peak of SCIP mRNA expression in crushed nerves.

suppressed fits the fact that SCIP mRNA is transiently reexpressed after transection of adult nerves.

These data lead us to revise the model of the role of SCIP in Schwann cells proposed by Monuki et al. (1990). They postulated that SCIP was expressed in proliferating Schwann cells that are in a transition state between "premyelinating" and myelinating Schwann cells, and that it serves to inhibit the expression of NGFR and the major myelin genes. This transient population of Schwann cells was postulated to exist in developing nerves, presumably associated with axons, as well as after axotomy of adult nerves. Our data lead to the following refinements in this model. First, SCIP is not exclusively expressed by proliferating Schwann cells, as exemplified by its expression in crushed/regenerating nerves. While proliferating Schwann cells express SCIP in some circumstances (such as forskolin-treated Schwann cells; Monuki et al., 1989), whether this is also true in developing nerves and degenerating nerves needs to be substantiated. Second, the model also needs to incorporate the finding that axon-Schwann cell interactions are necessary for high levels of SCIP expression. Ilence, axotomy does not lead to the formation of a population of transitory SCIP-positive cells unless it is followed by axonal regeneration. Third, SCIP is transiently expressed in ensheathing Schwann cells, but whether these cells are exclusively "promyelinating" (ensheathing axons in a 1:1 manner), rather than "premyelinating" (ensheathing axon bundles) and/or early myelinating Schwann cells, remains to be established.

\section{References}

Abney ER, Bartlett PP, Raff MC (1981) Astrocytes, ependymal cells, and oligodendrocytes develop on schedulc in dissociated cell cultures of embryonic rat brain. Dev Biol 83:301-310.

Asbury AK, Johnson PC (1978) Pathology of peripheral nerve. In: Major problems in pathology (Bennington JL, ed), p 311. Philadelphia: Saunders.

Baichwal RR, Bigbee JW, DeVries GH (1988) Macrophage-mediated myelin-related mitogenic factor for cultured Schwann cells. Proc Natl Acad Sci USA 85:1701-1705.

Benjamins JA, Jones M, Morell P (1975) Appearance of newly synthesized protein in myelin of young rats. J Neurochem $24: 1117-1122$.

Bolin LM, Shooter EM (1993) Neurons regulate Schwann cell genes by diffusible molecules. J Cell Biol 123:237-243.

Bradley WG, Asbury AK (1970) The duration of synthesis phase in neurilemma cells in mouse sciatic nerve during degeneration. Exp Neurol 26:275-382.

Brockes JP, Fields P, Raff MC (1979) Studies on cultured rat Schwann cells. I. Establishment of purified populations from cultures of peripheral nerve. Brain Res 165:105-118.

Brockes JP, Raff MC, Nishiguchi DJ, Winter J (1980) Studies on cultured rat Schwann cells. III. Assays for peripheral myelin proteins. J Neurocytol 9:67-77.

Brown MJ, Asbury AK (1981) Schwann cell proliferation in the postnatal mouse: timing and topography. Exp Neurol 74:170-186.

Carden MJ, Trojanowski JQ, Schlaepfer NW, Lee VM-Y (1987) Two- 
stage expression of neurofilament polypeptides during rat neurogenesis with early establishment of adult phosphorylation patterns. J Neurosci 7:3489-3504.

Chirgwin JM, Przbyla AE, MacDonald RJ, Rutter RJ (1979) Isolation of biologically active ribonucleic acid from sources enriched in ribonuclease. Biochemistry 18:5294-5299.

Collarini EJ, Kuhn R, Marshall CJ, Monuki ES, Lemke G, Richardson WD (1992) Down-regulation of the POU transcription factor SCIP is an early event in oligodendrocyte differentiation in vitro. Development 1 16:193-200

Fort P, Marty L, Piechaczyk M, Sabrouty SE, Dani C, Jeanteur P, Blanchard JM (1985) Various rat adult tissues express only one major mRNA species from the glyceraldehyde-3-phosphate-dehydrogenase multigenic family. Nucleic Acids Res 13:1431-1442.

Goto K, Kurihara T, Takahashi Y, Kondo H (1990) Expression of genes for the myelin-specific proleins in oligodendrocytes in vivo demands the presence of axons. Neurosci Lett 117:269-274.

Gupta SK, Poduslo JF, Mezei C (1988) Temporal changes in PO and $\mathrm{MBP}$ gene expression after crush-injury of the adult peripheral nerve. Brain Res 464:133-141.

Gupta SK, Poduslo JF, Dunn R, Roder J, Mezei C (1990) Myelinassociated glycoprotein gene expression in the presence and absence of Schwann cell-axonal contact. Dev Neurosci 12:22-30.

Gutmann E, Sanders FK (1943) Recovery of fibre number and diameter in the regeneration of peripheral nerves. J Physiol (Lond) 101: 489-518.

He X, Treacy MN, Simmons DM, Ingraham HA, Swanson LW, Rosenfeld MG (1990) Expression of a large family of POU-domain regulatory genes in mammalian brain development. Nature 340:3542.

He X, Gerrero R, Simmons DM, Park RE, Lin CR, Swanson LW, Rosenfeld MG (1991) Tst-1, a member of the POU domain gene family, binds the promoter of the gene encoding the cell surface adhesion molecule Po. Mol Cell Biol 11:1739-1744.

Kanfer J, Parenty M, Goujct-Zalc C, Munge M, Bernier L, Campagnoni AT, Dautigny A, Zalc B (1989) Developmental expression of myelin proteolipid protein, myelin basic protein, and $2^{\prime}, 3^{\prime}$-cyclic nucleotide $3^{\prime}$ phosphodiesterase transcripts in different rat brain regions. J Mol Neurosci 1:39-46.

Kidd GJ, Hauer PE, Trapp BD (1990) Axons modulate myelin protein messenger RNA levels during central nervous system myelination in vivo. J Neurosci Res 26:409-418.

Komiyama A, Suzuki K (1992) Age-related differences in proliferative responses of Schwann cells during Wallerian degeneration. Brain Res 573:267-275.

Kuhn R, Monuki ES, Lemke G (1991) The gene encoding the transcription factor SCIP has features of an expressed retroposon. Mol Cell Biol 11:4642-4650.

LeBlanc AC, Poduslo JF (1990) Axonal modulation of myelin gene expression in the peripheral nerve. J Neurosci Res 26:317-326.

Lemke G (1988) Unwrapping the gene of myelin. Neuron 1:535-543.

Lemke G, Axel R (1985) Isolation and sequence of a cDNA encoding the major structural protein of peripheral myelin. Cell 40:501-508.

Lemke G, Chao M (1988) Axons regulate Schwann cell expression of the major myelin and NGF receptor genes. Development 102:499 504.

McMorris FA (1983) Cyclic AMP induction of the myelin enzyme $2^{\prime}, 3^{\prime}$-cyclic nucleotide $3^{\prime}$-phosphohydrolase in rat oligodendrocytes. J Neurochem 41:506-515.

McPhilemy K, Mitchell LS, Griffiths IR, Morrison S, Deary AW, Sommer I, Kennedy PGE (1990) Effect of optic nerve transection upon myelin protein gene expression by oligodendrocytes: evidence for axonal influence on gene expression. $J$ Neurocytol 19:494-505.

Mira JC (1976) Etudes quantitatives sur la régénération des fibres nerveuses myelinisées. II. Variations du nombre et du calibre des fibres régénérées après un écrasement ou une section du nerf. Arch Anat Microsc Morphol Exp 65:255-284

Mirsky R, Jessen KR (1990) Schwann cell development and the regulation of myelination. Semin Neurosci 2:423-435.

Mirsky R, Winter J, Abney E, Pruss RM, Gavrilovic J, Raff MC (1980) Myelin-specific proteins and glycolipids in rat Schwann cells and oligodendrocytes in culture. J Cell Biol 84:483-494.

Mitchell LS, Griffiths IR, Morrison S, Barrie JA, Kirkham D, McPhilemy K (1990) Expression of myelin protein gene transcripts by Schwann cells of regenerating nerve. J Neurosci Res 27:125-135.
Mokuno K, Sobue G, Reddy UR, Wurzer J, Kreider B, Hotta H, Baron P, Ross AH, Pleasure D (1988) Regulation of Schwann cell nerve growth factor receptor by cyclic adenosine $3^{\prime}, 5^{\prime}$-monophosphate. J Neurosci Res 21:465-472.

Monuki ES, Weinmaster G, Kuhn R, Lemke G (1989) SCIP: a glial cell POU domain gene regulated by cyclic AMP. Neuron 3:783-793.

Monuki ES, Kuhn R, Weinmaster G, Trapp BD, Lemke G (1990) Expression and activity of the POU transcription factor SCIP. Science 249:1300-1303.

Monuki FS, Kuhn R, Lemke G (1993) Repression of the myelin P0 gene by the POU transcription factor SCIP. Mech Dev 42:15-32.

Morgan L, Jessen KR, Mirsky R (1991) The effects of cAMP on differentiation of cultured Schwann cclls: progression from an early phenotype $(04+)$ to a myelin phenotype (Po-, GFAP-, N-CAM-, NGF-receptor-) depends on growth inhibition. J Cell Biol 112:457467.

Morris JH, Hudson AR, Weddell AGM (1972) A study of degeneration and regeneration in the divided rat sciatic nerve base on electron microscopy. I-IV. Z Zellforsch Mikrosk Anat 124:76-203.

Morrison S, Mitchell LS, Ecob-Prince MS, Griffiths IR, Thomson CE, Barrie JA, Kirkham D (1991) P0 gene expression in cultured Schwann cells. J Neurocytol 20:769-780.

Norton WT, Cammer W (1984) Isolation and characterization of myelin. In: Myelin (Morrell P, ed), pp 147-195. New York: Plenum.

Pelligrino RG, Spencer PS (1985) Schwann cell mitosis in response to regenerating axons in vivo. Brain Res 431:16-25.

Plumb M, Stcin J, Stcin G (1983) Coordinate regulation of multiple histone mRNAs during the cell cycle in HeLa cells. Nucleic Acids Res 11:2391-2410.

Radeke MJ, Misko TP, Hsu C, Herzenberg LA, Shooter EM (1987) Gene transfer and molecular cloning of the rat nerve factor receptor. Nature 325:593-597.

Ratner N, Hong DM, Lieberman MA, Bunge RP, Glaser L (1988) The neuronal cell-surface molecule mitogenic for Schwann cells is a heparin-binding protein. Proc Natl Acad Sci USA 85:6992-6996.

Richardson KC, Jarett L, Finke EH (1960) Embedding in epoxy resins for ultrathin sectioning in electron microscopy. Stain Technol 35:313.

Salzer JI, Bunge RP (1980) Studies of Schwann cell proliferation. I. An analysis in tissue culture of proliferation during development, Wallerian degeneration, and direct injury. J Cell Biol 84:739-752.

Salzer JL, Williams AK, Glaser L, Bunge RP (1980a) Studies of Schwann cell proliferation. II. Characterization of the stimulation and specificity of the response to a neurite membrane fraction. J Cell Biol 84 : 753-766.

Salzer JL, Bunge RP, Glaser L (1980b) Studies of Schwann cell proliferation. III. Evidence for the surface localization of the neurite mitogen. J Cell Biol 84:767-778.

Sambrook J, Fritsch EF, Maniatis T (1989) Molecular cloning: a laboratory manual. Cold Spring Harbor, NY: Cold Spring Harbor Laboratory.

Scherer SS, Asbury AK (1993) Inherited axonal neuropathies. In: The molecular and genetic basis of neurological disease (Rosenberg RN, Prusiner SB, DiMauro S, Barchi RL, Kunkle LM, eds), pp 899-921. Boston: Butterworth-Heinemann.

Scherer SS, Easter SS Jr (1984) Degencrative and regenerative changes in the trochlear nerve of goldfish. J Neurocytol 13:519-565.

Scherer SS, Vogelbacker HH, Kamholz J (1992) Axons modulate the expression of proteolipid protein in the CNS. J Neurosci Res 32:138148.

Scherer SS, Kamholz J, Jakowlew SB (1993) Axons modulate the expression of transforming growth factor-betas in Schwann cells. Glia 8:265-276.

Snipes GJ, Suter U, Welcher AA, Shooter EM (1992) Characterization of a novel peripheral nervous system myelin protein (PMP-22/SR 13 ). J Cell Biol 117:225-238.

Spreyer P, Kuhn G, Hanemann CO, Gillen C, Schaal H, Kuhn R, Lemke G, Muller HW (1991) Axon-regulated expression of a Schwann cell transcript that is homologous to a "growth-arrest-specific" gene. EMBO J 10:3661-3668.

Stahl N, Harry J, Popko B (1990) Quantitative analysis of myelin protein gene expression during development in the rat sciatic nerve. Mol Brain Res 8:209-212.

Suzuki N, Rohdewohld H, Neuman T, Gruss P, Scholer HR (1990) Oct-6: a POU transcription factor expressed in embryonal stem cells and in the developing brain. EMBO J 9:3723-3732. 
Taniuchi M, Clark HB, Johnson EM Jr (1986) Induction of nerve growth factor receptor in Schwann cells after axotomy. Proc Natl Acad Sci USA 83:4094-4098.

Taniuchi M, Clark HB, Schweitzer JB, Johnson EM Jr (1988) Expression of nerve growth factor receptors by Schwann cells of axotomized peripheral nerves: ultrastructural location, suppression by axonal contact, and binding properties. J Neurosci 8:664-681.

Toews AD, Eckermann CE. Roberson MD. Lee SY. Morell P (1991) Primary demyelination induced by exposure to tellurium alters messenger RNA levels for nerve growth factor receptor, SCIP, $2^{\prime}, 3^{\prime}$-cyclic nuclcotide 3 '-phosphodiesterase, and myelin proteolipid protein in rat sciatic nerve. Mol Brain Res 11:321-325.

Trapp BD, Haver P, Lemke G (1988) Axonal regulation of myclin protein mRNA levels in actively myelinating Schwann cells. J Neurosci $8: 3515-3521$

Uyemura K, Horie K, Kitamura K, Suzuki M, Uehara S (1979) Developmental changes of myelin protein in the chick peripheral nerve. J Neurochem 32:779-788.

Webster HD, Favilla JT (1984) Development of peripheral nerve fi- bers. In: Peripheral ncuropathy (Dyck PJ, Thomas PK. Lambert EH, Bunge R, eds), pp 329-359. Philadelphia: Saunders.

Wiktorowicz M, Roach A (1991) Regulation of myelin basic protein gene transcription in normal and shiverer mutan 1 mice. Dev Neurosci 13:143-150.

Winter J, Mirsky R, Kadlubowski M (1982) Immunocytochemical study of the appearance of $P_{2}$ in developing rat peripheral nerve: comparison with other myelin components. J Neurocytol 11:351362 .

Wood JG, Engel EL (1976) Peripheral nerve glycoproteins and myelin fine structure during development of rat sciatic nerve. J Neurocytol $5: 605-615$

Wood PM, Bunge RP (1975) Evidence that sensory axons are mitogenic for Schwann cells. Nature 256:662-664

Zeller NK, Behar TN, Dubois-Dalcq ME, Lazzarini RA (1985) The timely expression of myelin basic protein gene in cultured rat brain oligodendrocytes is independent of continuous neuronal influences. J Neurosci 5:2955-2962. 